\title{
Viral Etiologies of Meningitis in Patients with Presumed Pyogenic Meningitis at University Hospitals in Ethiopia
}

\author{
Alene Geteneh (1D' \\ Tesfaye Kassa (iD) ${ }^{2}$ \\ Derbie Alemu ${ }^{3}$ \\ Mulugeta Kiros iD ${ }^{4}$ \\ Henok Andualem (iD) 4 \\ Admasu Tenna ${ }^{5}$ \\ Abebech Tesfaye ${ }^{6}$ \\ Dawit Hailu Alemayehu ${ }^{6}$ \\ Adane Mihret ${ }^{6}$ \\ Rawleigh Howe ${ }^{6}$ \\ Andargachew Mulu ${ }^{6}$ \\ Wude Mihret ${ }^{6}$ \\ 'Department of Medical Laboratory \\ Science, College of Health Science, \\ Woldia University, Woldia, Ethiopia; \\ ${ }^{2}$ School of Medical Laboratory Science, \\ Jimma University, Jimma, Ethiopia; \\ ${ }^{3}$ Department of Medical Laboratory \\ Science, Arba Minch College of Health \\ Science, Arba Minch, Ethiopia; \\ ${ }^{4}$ Department of Medical Laboratory \\ Science, College of Health Science, \\ Debre Tabor University, Debre Tabor, \\ Ethiopia; ${ }^{5}$ School of Medicine, Addis \\ Ababa University, Addis Ababa, Ethiopia; \\ ${ }^{6}$ Armauer Hansen Research Institute, \\ Addis Ababa, Ethiopia
}

This article was published in the following Dove Press journal: Infection and Drug Resistance

\begin{abstract}
Introduction: Viral meningitis is common in most resource-limited settings, posing a challenge for the management and prognosis of suspected patients. No study has been done on the detection of either viral or viral-bacterial co-infection among presumed pyogenic meningitis cases in Ethiopia. We, therefore, aimed to determine the distribution of cytomegalovirus (CMV) and human enteroviruses (HEVs) among patients with presumptive pyogenic meningitis at University hospitals in Ethiopia.
\end{abstract}

Methods: Viral nucleic acid was extracted from 86 repository CSF samples, which were collected from patients presumptively diagnosed with pyogenic meningitis between 2012 and 2013. PCR was done consecutively to investigate the possible viral etiologic agents of meningitis.

Results: HEVs were detected in $11(12.8 \%)$ of the analyzed samples while none of the 86 samples were tested positive for CMV. Viral-bacterial co-infections were found among 4/11 (36.4\%) confirmed cases. The majority of the patients (10/11) with HEVs were younger aged $\leq 19$ years old.

Conclusions: In this study, the magnitude of HEVs was shown to have a significant role in presumed pyogenic meningitis cases. Therefore, we recommend presumed pyogenic meningitis cases to be inspected for viral etiologies and improve meningeal symptoms interpretations.

Keywords: pyogenic meningitis, viral meningitis, human enteroviruses, Ethiopia

\section{Introduction}

Aseptic meningitis has been posing a challenge globally. Depending mainly on the immune status, the age of the patient, as well as the specific viral agent causing the disease, the illness can range from an asymptomatic course to a serious case with possible fatal outcomes. ${ }^{1}$ Of the many infectious and non-infectious agents, viruses are the most common causes of aseptic meningitis. ${ }^{2-4}$ Human enteroviruses (HEVs) have been reported as the primary cause of viral meningitis, accounting for more than $85 \%$ of all global cases, ${ }^{5}$ while human herpesviruses (mainly HHV-1 to 5) have been causing $4 \%$ of the meningitis cases globally. ${ }^{6}$ Patients with presumed pyogenic meningitis are more likely to acquire respiratory viral infections, such as HEVs. Such incidences were observed in past meningococcal meningitis epidemics. $^{7}$

The overlapping clinical features of meningitis caused by different etiologic agents is a diagnostic problem in developing countries including Ethiopia owing to
Correspondence: Alene Geteneh Email aleneget@gmail.com
Infection and Drug Resistance 2021:14 1083-1088

1083 
a shortage of finance, expendable supplies, and laboratory facilities. $^{8-10}$ The clinicians from developing settings mainly depend on clinical investigation and their medical judgments and experience to distinguish between bacterial and viral meningitis, and these clinical assessments could result in misdiagnosis. ${ }^{11}$ The turbid CSF may not guarantee the absence of viral etiologies of meningitis. ${ }^{12,13}$ Therefore, identifying viral and bacterial etiologic agents of meningitis is an essential step for better management and prognosis of suspected patients. In our previous study, about $67 \%$ of patients with presumptive pyogenic meningitis tested negative for the common bacterial etiologies. ${ }^{14}$ This study was aimed at determining the magnitude and etiologic agents of viral meningitis among patients presumptively diagnosed as pyogenic meningitis.

\section{Materials and Methods Study Setting}

A cross-sectional study was conducted on repository samples, which were collected from three teaching hospitals in Ethiopia; Tikur Anbessa specialized hospital, Hawassa University teaching hospital, and University of Gondar hospital in collaboration with Armauer Hanson Research Institute (AHRI). All of these institutions are full-fledged government-affiliated University hospitals serving as referral hospitals and are located in the meningitis belt of the Africa region. Between 2012 and 2013, CSF samples were collected from patients suspected of pyogenic meningitis, as part of the clinical workup and consecutively stored at AHRI.

\section{Inclusion Criteria}

Pyogenic/bacterial meningitis is defined by the presence of polymorphonuclear leukocytes (pus cells) in CSF, turbid appearance of CSF besides the meningeal symptoms. However, our previous study included not only turbid but also clear CSF samples for bacterial detection, as clearness of CSF could not assure the absence of bacterial causes of meningitis. ${ }^{14}$ Hence, all patients who were clinically diagnosed with pyogenic meningitis in 2012/2013 at three teaching hospitals that had a stored CSF sample and complete data record were consecutively included in this study regardless of their sex and age. Accordingly, a total of $86 \mathrm{CSF}$ samples with complete data were included in the current study. These samples were previously characterized as PCR positive (32) and PCR Negative (54) for bacterial etiologies in our previous study. The three common bacterial etiologies previously detected among those PCR positive were $N$. meningitidis, S. pneumoniae, and H. influenzae. ${ }^{14}$

\section{Cytomegalovirus PCR Amplification}

DNA was first extracted using QIAamp DNA Mini Kit (Qiagen, Hilden, Germany) following the manufacturer's instruction. Conventional PCR was then carried out in a 25 $\mu \mathrm{L}$ reaction mix consisting of $12.5 \mu \mathrm{L}$ Platinum $^{\mathrm{TM}}$ Hot Start PCR Master Mix (Invitrogen; the United States), $1 \mu \mathrm{L}$ of each $(10 \mu \mathrm{M})$ HCMV forward primer (5'TCGACGTTTCCACACAGACATG-3') and HCMV reverse primer (5'-GTGGTAGAAGCGGCGAAAGG-3'), $5.5 \mu \mathrm{L}$ molecular grade water, and $5 \mu \mathrm{L}$ of template DNA. The thermal cycling condition includes initial denaturation at $95{ }^{\circ} \mathrm{C}$ for $15 \mathrm{~min}, 35$ cycles with denaturation at $95{ }^{\circ} \mathrm{C}$ for 30 seconds, annealing at $60{ }^{\circ} \mathrm{C}$ for $30 \mathrm{sec}$, and elongation at $72^{\circ} \mathrm{C}$ for $45 \mathrm{sec}$ followed by a final extension at $72{ }^{\circ} \mathrm{C}$ for 10 minutes. ${ }^{15} 2 \%$ agarose gel electrophoresis was performed to confirm the amplified PCR product (729 bp).

\section{Human Enteroviruses RT-PCR}

RNA was extracted using the Abbott Real-time HIV-1 M2000rt machine (Abbott Laboratories, Abbott Park, USA). Two-step RT-PCR was conducted for the amplification of HEVs. HEVs specific primers used were PanEV2-5'NTR F: 5'-CATGGTGCGAAGAGTCGATTG A-3' and PanEV2-5'NTR R: 5'-CACCCAAAGTAGTC GGTTCCGC-3' (144bp) to detect all HEVs. ${ }^{16}$ Reverse transcription was performed in a $20 \mu \mathrm{L}$ reaction mix; with $15 \mu \mathrm{L}$ master mix composed of $2 \mu \mathrm{L}$ of $10 \mathrm{x}$ RT buffer, $1 \mu \mathrm{L}$ of $10 \mathrm{mM}$ each dNTP, $2 \mu \mathrm{L}$ of reverse primer $(10 \mu \mathrm{M}), 0.5 \mu \mathrm{L}$ of RNase inhibitor (40 units $/ \mu \mathrm{L}), 1 \mu \mathrm{L}$ of Omniscript reverse transcriptase, $8.5 \mu \mathrm{L}$ RNase-free water and $5 \mu \mathrm{L}$ template RNA. The reaction mixture was then incubated at $37^{\circ} \mathrm{C}$ for 60 minutes to synthesis cDNA. PCR amplification was done by adding $5 \mu \mathrm{L}$ cDNA to $15 \mu \mathrm{L}$ PCR master mix (constituting of $10 \mu \mathrm{L}$ hot start mix, $1 \mu \mathrm{L}$ of forward and reverse primer each $[10 \mu \mathrm{M}]$ and $3 \mu \mathrm{L}$ molecular grade water). The thermal cycling was adjusted at $95^{\circ} \mathrm{C}$ for 15 minutes, and 45 cycles of denaturation at $95{ }^{\circ} \mathrm{C}$ for $3 \mathrm{~s}$, followed by annealing and extension at $60^{\circ} \mathrm{C}$ for 60 seconds. The amplicon was visualized on $1.5 \%$ agarose gel. This protocol was modified from a previously published article. ${ }^{16}$ 
Table I Bivariate Correlation of Demographic and Clinical Variables with PCR Positivity for HEVs at AHRI, 2019

\begin{tabular}{|c|c|c|c|c|c|c|}
\hline \multicolumn{2}{|l|}{ Variables } & \multicolumn{2}{|l|}{ HEVs } & \multirow{3}{*}{$\begin{array}{l}\text { p-value } \\
0.049\end{array}$} & \multirow{3}{*}{$\begin{array}{l}\text { COR } \\
8.29 \\
1\end{array}$} & \multirow{3}{*}{$\begin{array}{l}\text { 95\% C.I. } \\
1.01,68.1\end{array}$} \\
\hline & & \multirow{2}{*}{$\begin{array}{l}\text { Positive (\%) } \\
10(19.6) \\
\text { I (2.9) }\end{array}$} & \multirow{2}{*}{$\begin{array}{l}\text { Negative (\%) } \\
41(80.4) \\
34(97.1)\end{array}$} & & & \\
\hline Age & $\begin{array}{l}0-19 \text { yrs. } \\
19+\text { yrs. }\end{array}$ & & & & & \\
\hline Sex & $\begin{array}{l}\text { Male } \\
\text { Female }\end{array}$ & $\begin{array}{l}8(15.7) \\
3(8.3)\end{array}$ & $\begin{array}{l}43(84.3) \\
32(91.7)\end{array}$ & 0.34 & $\begin{array}{l}0.5 \\
1\end{array}$ & $0.12,2.05$ \\
\hline Fever & $\begin{array}{l}\text { Yes } \\
\text { No }\end{array}$ & $\begin{array}{l}8(13.3) \\
3(11.5)\end{array}$ & $\begin{array}{l}52(86.7) \\
23(88.5)\end{array}$ & 0.82 & $\begin{array}{l}0.85 \\
I\end{array}$ & $0.21,3.49$ \\
\hline Impaired consciousness & $\begin{array}{l}\text { Yes } \\
\text { No }\end{array}$ & $\begin{array}{l}7(14.6) \\
4(10.5)\end{array}$ & $\begin{array}{l}41(85.4) \\
34(89.5)\end{array}$ & 0.58 & $\begin{array}{l}1.45 \\
1\end{array}$ & $0.39,5.38$ \\
\hline Vomiting & $\begin{array}{l}\text { Yes } \\
\text { No }\end{array}$ & $\begin{array}{l}8(13.3) \\
3(11.5)\end{array}$ & $\begin{array}{l}52(86.7) \\
23(88.5)\end{array}$ & 0.82 & $\begin{array}{l}0.85 \\
I\end{array}$ & $0.21,3.49$ \\
\hline Stiffness & $\begin{array}{l}\text { Yes } \\
\text { No }\end{array}$ & $\begin{array}{l}5(9.4) \\
6(18.2)\end{array}$ & $\begin{array}{l}48(90.6) \\
27(81.8)\end{array}$ & 0.25 & $\begin{array}{l}2.1 \\
1\end{array}$ & $0.6,7.65$ \\
\hline Seizure & $\begin{array}{l}\text { Yes } \\
\text { No }\end{array}$ & $\begin{array}{l}6(17.6) \\
5(9.6)\end{array}$ & $\begin{array}{l}28(82.4) \\
47(80.4)\end{array}$ & 0.28 & $\begin{array}{l}0.5 \\
1\end{array}$ & $0.14,1.78$ \\
\hline CSF appearance & $\begin{array}{l}\text { Clear } \\
\text { Turbid }\end{array}$ & $\begin{array}{l}5(17.2) \\
6(10.5)\end{array}$ & $\begin{array}{l}24(82.8) \\
51(89.5)\end{array}$ & 0.38 & $\begin{array}{l}0.57 \\
I\end{array}$ & $0.16,2.04$ \\
\hline
\end{tabular}

Abbreviations: yrs., years; Fever, temperature $\geq 38$ o c; COR, crude odds ratio; $\mathrm{Cl}$, confidence interval.

\section{Quality Control}

Positive controls from NATrol (Helvetica Health Care, Geneva Switzerland) and molecular grade water were used as positive and negative quality controls respectively to assure the quality of the laboratory result.

\section{Statistical Analysis}

Data were checked and cleared for incompleteness and then entered into Epi-data version 3.1. SPSS v25.0 was used for statistical analysis. Bivariate analysis was performed to test for association between dependent and independent variables. An association with a p-value $<0.05$ was considered statistically significant.

\section{Ethical Approval}

Before data extraction and utilization of the stored samples, an ethical issue specifically, waiver of consent was obtained from the AHRI/ALERT ethics review committee. The review committee has also approved the study protocol with a reference number Reg.PO14/18.

\section{Result}

A total of 86 presumptively diagnosed pyogenic meningitis patients were enrolled in this study. Of these, 59.3\% $(\mathrm{n}=51)$ were male patients with a male to female proportions of 1.46:1. The age of patients varies from 2 days to 78 years old. About $70 \%$ of the patients $(n=60)$ were from the University of Gondar hospital. The overall magnitude of HEVs among patients presumptively diagnosed as pyogenic meningitis was $12.8 \%$ (11/86), while they all have tested negative for CMV. The majority of the study participants were in age between 2 days to 19 years old $(\mathrm{n}=51)$ and tuned to have a higher HEVs positivity rate (19.6\%) (Table 1.). The younger age of patients was associated with HEVs positivity $(\mathrm{p}<0.05)$. Despite this, none of the clinical characteristics showed a significant association with HEVs meningitis (Table 1.). Among the 11 cases for HEVs meningitis, 10 were aged less than 19 years old. Most of these HEVs positive individuals' had fever (8/10), impaired consciousness (7/ $10)$, vomiting $(7 / 10)$, and seizure (6/10). Half of the patients with HEVs (under 19 years) had turbid CSF appearance; which could be suggestive of the need for inspection of turbid CSF samples for viral etiologies. The overall association of dependent and independent variables is summarized in (Table 1.).

Among those HEVs positive individuals, 4 (4/11: $36.4 \%$ ) of them were co-infected with at least one bacterial pathogen. Specifically, of those previously PCR positive 
Table 2 PCR Findings with Specific Etiologic Agents in Patients Presumptively Diagnosed Pyogenic Meningitis at AHRI, 2019

\begin{tabular}{|c|c|c|c|c|}
\hline \multirow[t]{2}{*}{ PCR Finding } & \multicolumn{3}{|c|}{ Bacteria Identified } & \multirow[t]{2}{*}{ Total } \\
\hline & No & N. meningitidis & S. pneumoniae & \\
\hline Negative & 47 & 0 & 0 & 47 \\
\hline Positive for bacteria & 0 & 18 & 10 & 28 \\
\hline Positive for Enteroviruses* & 7 & 0 & 0 & 7 \\
\hline Positive for bacteria + Enteroviruses* & 0 & 3 & 1 & 4 \\
\hline Total & 54 & 21 & 11 & 86 \\
\hline
\end{tabular}

Note: *CMV was negative in all assayed samples.

for $N$. meningitides $(\mathrm{n}=21)$ and $S$. pneumoniae $(\mathrm{n}=11)$ samples, ${ }^{14}$ three and one patients were concomitantly infected with HEVs, respectively (Table-2.). Among the presumptively diagnosed patients and confirmed PCR negatives $(\mathrm{n}=54)$ for the three common bacterial etiologies ( $N$. meningitides, $S$. pneumoniae, and H. influenzae), ${ }^{14}$ 7 were positive for enteroviruses in the current study.

Nearly $13 \%$ (7/54) of the patients negative for common bacterial causes of meningitis were misdiagnosed for pyogenic meningitis or infected with pathogens not included in the diagnostic panel of our previous study; ${ }^{14}$ while $12.5 \%(4 / 32)$ of the confirmed pyogenic meningitis cases were co-infected with enteroviruses.

The outcome of patients was examined after their discharge. The overall death was reported in 10 of the 86 study participants $(11.6 \%), 3$ patients with confirmed bacterial meningitis ( $S$. pneumoniae). Seven dead patients were negative for the common bacterial etiologies (N. meningitidis, S. pneumoniae, and $H$. influenzae), HEVs, and CMV. The cause of the death might be due to the less common bacterial agents or other viruses. None of the HEVs positive patients have died nor reported developing any sequelae (all of them fully recovered without distinct disability and impact).

\section{Discussion}

Viral central nervous system (CNS) infections remain a major public health concern, because of the associated morbidity and mortality. Viral meningitis is a relatively neglected area of medicine in the developing world since they require advanced laboratory settings. ${ }^{17}$ Among the viral etiologic agents responsible for meningitis, HEVs remain to be the predominant pathogens in both children and adults. ${ }^{4,18}$ In the current study, viral pathogens were detected in $12.8 \%(11 / 86)$ of patients presumptively diagnosed as pyogenic meningitis in both confirmed and non-confirmed meningitis cases.

The finding in the current study was relatively lower as compared to the majority of studies in European countries; Georgia (18.6\%), ${ }^{11}$ France (43.4\%), ${ }^{19}$ Greece $(28.8 \%),{ }^{18}$ England (47\%), ${ }^{4}$ Germany $(36 \%),{ }^{20}$ Ireland $(61.9 \%),{ }^{21}$ Asian countries; China (37.7\%), ${ }^{22}$ Iran (18-43.3), ${ }^{23-25}$ and South Korea (38.4\%), ${ }^{26}$ and the USA (35.5\%). ${ }^{27}$ The possible reasons for such variations in the distribution of the viral pathogen may be differences in the study population, age, season of case occurrence, and inflammatory changes. ${ }^{20,24-26}$ The other difference could be explained by the fact that this study was conducted on presumed pyogenic meningitis, while other studies sampled presumed viral meningitis cases. ${ }^{1}$

Our study did not detect CMV, which was expected since the herpesviruses family collectively causes about $4 \%$ of viral meningitis cases, mostly by herpes simplex virus (HSV-2). ${ }^{6}$ However, the zero prevalence was very lower compared to the finding in Iraq $(8.4 \%)^{28}$ and Malawi (14\%), Sub-Saharan Africa. ${ }^{29}$ This could be due to the variation in the spectrum of causes of viral meningitis in a given population.

Studies show that HEV's positivity varies with age. ${ }^{1,25}$ For example, in Iran neonates were more (37.1\%) affected than children $(34.7 \%){ }^{25}$ In South Korea, the younger ages had a lower percentage of lymphocyte, and lower CSF protein levels, suggestive for HEVs meningitis. ${ }^{26}$ These study findings were in line with the current study since younger-aged patients were shown to have more HEVs meningitis (19.6\%) (Table 1). Viral meningitis was thought to vary between $14-25 \%$ in Africa. ${ }^{12}$ However, our finding was lower similar to the finding in Angola; where HEVs were detected in 3\% of children with presumed bacterial meningitis, ${ }^{12} 9.8 \%$ of patients with a sign of meningitis in Tunisia. ${ }^{9}$ In Uganda and Malawi, viruses had attributed for $5.9 \%{ }^{10}$ and $26 \%{ }^{30}$ of children CNS 
infections, respectively. The difference in clinical/presumptive diagnosis and study participants may be the reason for the observed variations.

The Enteroviral contribution of meningitis at Jimma university medical center, Ethiopia ${ }^{31}$ was $9 \%$, which was comparable with our finding (12.8\%). However, the use of pan-enteroviruses primer which can detect multiple numbers of HEVs may increase our study detection rate. The burden and specific causes of viral meningitis had shown a slight variation with geographic location and study subjects.

This study has found four simultaneous bacterial and viral CNS co-infections (3 HEVs $+N$. meningitides and 1 HEVs $+S$. pneumoniae) (Table 2.). Similar to our finding, four patients were co-infected with bacteria or malaria in Angola, ${ }^{12}$ one patient was shown to had both Enterovirus and $S$. pneumoniae in Georgia, ${ }^{11}$ Uganda, ${ }^{10}$ and Iran (Enterovirus $+K$. pneumoniae) ${ }^{25}$ Among the 27 childhood viral CNS infections reported from Uganda, 8 were due to CMV (6 occurred concomitantly with bacterial agents), ${ }^{10}$ and in Malawi, 9\% of patients were known to have malaria and CNS virus. These study findings have shown the frequent occurrence of concomitant CNS infections in confirmed viral or bacterial meningitis cases. ${ }^{10,11,25}$

To our knowledge, this study is the first study to explore concomitant bacterial-viral CNS infections in Ethiopia. However, our study was having limitations concerning the inclusion of data from CSF cellular and chemical profile, and the small sample size constrained to assess possible associated factors with HEVs meningitis. The detection of enteroviruses in suspected bacterial meningitis cases, and that co-infections directs the need to inspect turbid CSFs for viral etiologies and improve interpretations of meningeal symptoms.

\section{Acknowledgments}

We would like to forward our gratitude to the AHRI staff, particularly the molecular lab staff.

\section{Author Contributions}

All authors made substantial contributions to conception and design, acquisition of data, or analysis and interpretation of data, took part in drafting the article or revising it critically for important intellectual content; agreed to submit to the current journal; gave final approval of the version to be published, and agreed to be accountable for all aspects of the work.

\section{Disclosure}

The authors report no conflicts of interest for this work.

\section{References}

1. de Oliveira DB, Candiani TM, Franco-Luiz APM, et al. Etiological agents of viral meningitis in children from a dengue-endemic area, Southeast region of Brazil. J Neurol Sci. 2017;375:390-394. doi:10.1016/j.jns.2017.02.025

2. Hasbun R, Rosenthal N, Balada-Llasat J, et al. Epidemiology of Meningitis and Encephalitis in the United States, 2011-2014. Clin Infect Dis. 2017;65(3):359-363.

3. Polage CR, Cohen SH. State-of-the-art microbiologic testing for community-acquired meningitis and encephalitis. J Clin Microbiol. 2016;54(5):1197-1202.

4. Heli Harvala PS. Viral meningitis - epidemiology and diagnosis Lancet Infect Dis. 2016.

5. Leber AL, Everhart K, Balada-Llasat JM, et al. Multicenter evaluation of BioFire FilmArray meningitis/encephalitis panel for detection of bacteria, viruses, and yeast in cerebrospinal fluid specimens. $J$ Clin Microbiol. 2016;54(9):2251-2261.

6. Azadfar S, Cheraghali F, Moradi A, Javid N, Tabarraei A. Herpes simplex virus meningitis in children in South East of caspian sea, iran. Jundishapur J Microbiol. 2014;7(1):e8599.

7. Moore PS, Hierholzer J, DeWitt W, et al. Respiratory viruses and mycoplasma as cofactors for epidemic group A meningococcal meningitis. JAMA. 1990;264(10):1271-1275.

8. Gudina EK, Tesfaye M, Adane A, et al. Challenges of bacterial meningitis case management in low income settings: an experience from Ethiopia. Trop Med Int Health. 2016;21(7):870-878.

9. Ines Othman RV, Elargoubi A, Guediche MN, et al. Enterovirus meningitis in Tunisia (Monastir, Mahdia, 2011-2013): identification of virus variants cocirculating in France. Diagn Microbiol Infect Dis. 2016;84:116-122.

10. Page A-L, Boum IY, Kemigisha E, et al. Aetiology and outcomes of suspected infections of the central nervous system in children in Mbarara, Uganda. Sci Rep. 2017;7(1):2728. doi:10.1038/s41598017-02741-w

11. Akhvlediani T, Bautista CT, Shakarishvili R, et al. Etiologic agents of central nervous system infections among febrile hospitalized patients in the country of Georgia. PLoS One. 2014;9(11):e111393. doi:10.1371/journal.pone. 0111393

12. Pelkonen T, Roine I, Anjos E, et al. Picornaviruses in cerebrospinal fluid of children with meningitis in Luanda, Angola. $J$ Med Virol. 2012;84(7):1080-1083. doi:10.1002/jmv.23304

13. Sferra T, Pacini D. Simultaneous recovery of bacterial and viral pathogens from cerebrospinal fluid. Pediatr Infect Dis J. 1988;7 (8):552-556.

14. Mihret W, Lema T, Merid Y, et al. Surveillance of bacterial meningitis, Ethiopia, 2012-2013. Emerg Infect Dis. 2016;22(1):75.

15. Schindele B, Apelt L, Hofmann J, et al. Improved detection of mutated human cytomegalovirus UL97 by pyrosequencing. Antimicrob Agents Chemother. 2010;54(12):5234-5241.

16. Pabbaraju K, Wong S, Wong AA, Tellier R. Detection of enteroviruses and parechoviruses by a multiplex real-time RT-PCR assay. Mol Cell Probes. 2015;29(2):81-85.

17. Baumgartner W, Loscher W. Re-emergence of neuroinfectiology. Acta Neuropathol. 2016;131(2):155-158.

18. Papa A, Papadopoulou E. Acute viral infections of the central nervous system, 2014-2016, Greece. J Med Virol. 2018;90 (4):644-647.

19. Jarrin I, Sellier P, Lopes A, et al. Etiologies and management of aseptic meningitis in patients admitted to an internal medicine department. Medicine (Baltimore). 2016;95(2):e2372.

20. Kaminski M, Grummel V, Hoffmann D, Berthele A, Hemmer B. The spectrum of aseptic central nervous system infections in southern Germany-demographic, clinical and laboratory findings. Eur J Neurol. 2017;24(8):1062-1070. 
21. Kelly TA, O’Lorcain P, Moran J, et al. Underreporting of viral encephalitis and viral meningitis, Ireland, 2005-2008. Emerg Infect Dis. 2013;19(9):1428.

22. Ai J, Xie Z, Liu G, et al. Etiology and prognosis of acute viral encephalitis and meningitis in Chinese children: a multicentre prospective study. BMC Infect Dis. 2017;17(1):494.

23. Hosseininasab A, Alborzi A, Ziyaeyan M, et al. Viral etiology of aseptic meningitis among children in southern Iran. J Med Virol. 2011;83(5):884-888.

24. Sadeghi F, Talebi-Nesami M, Barari-Savadkouhi R, Bijani A, Ferdosi-Shahandashti E, Yahyapour Y. Human enteroviruses in cerebrospinal fluid of children with suspected aseptic meningitis: a study in northern Iran. Caspian J Intern Med. 2017;8(2):112-115.

25. Shahroodi MJG, Ghazvini K, Sadeghi R, Sasan MS. Enteroviral Meningitis in neonates and children of Mashhad, Iran. Jundishapur J Microbiol. 2016;9:5.

26. Han SH, Choi HY, Kim JM, Park KR, Youn YC, Shin HW. Etiology of aseptic meningitis and clinical characteristics in immune-competent adults. J Med Virol. 2016;88(1):175-179.
27. Shukla B, Aguilera EA, Salazar L, Wootton SH, Kaewpoowat Q, Hasbun R. Aseptic meningitis in adults and children: diagnostic and management challenges. J Clin Virol. 2017;94:110-114.

28. Mohammed AH. Detection of human cytomegalovirus in patients with meningitis by using real time PCR. J Coll Educ Pure Sci. 2018;8(1):14-23.

29. Benjamin LA, Kelly M, Cohen D, et al. Detection of herpes viruses in the cerebrospinal fluid of adults with suspected viral meningitis in Malawi. Infection. 2013;41(1):27-31.

30. Mallewa M, Vallely P, Faragher B, et al. Viral CNS infections in children from a malaria-endemic area of Malawi: a prospective cohort study. Lancet Glob Health. 2013;1(3):e153-e160.

31. Barnes GK, Gudina EK, Berhane M, et al. New molecular tools for meningitis diagnostics in Ethiopia - a necessary step towards improving antimicrobial prescription. BMC Infect Dis. 2018;18(1):684.

\section{Publish your work in this journal}

Infection and Drug Resistance is an international, peer-reviewed openaccess journal that focuses on the optimal treatment of infection (bacterial, fungal and viral) and the development and institution of preventive strategies to minimize the development and spread of resistance. The journal is specifically concerned with the epidemiology of antibiotic resistance and the mechanisms of resistance development and diffusion in both hospitals and the community. The manuscript management system is completely online and includes a very quick and fair peerreview system, which is all easy to use. Visit http://www.dovepress.com/ testimonials.php to read real quotes from published authors. 